ISSN 1979-9950 (print) || ISSN 2598-0033 (online), http://jurnal.umsu.ac.id/index.php/intiqad DOI: https://doi.org/10.30596/intiqad.v10i1.1924

Published June 2018

\title{
Pengaruh Burnout Terhadap Kinerja Karyawan Pada BMT El-Munawar Medan
}

\author{
Isra Hayati $^{1 *}$, Suci Fitria ${ }^{2}$ \\ Universitas Muhammadiyah Sumatera Utara \\ email: israhayati@umsu.ac.id
}

\begin{abstract}
Abstrak
Tujuan dari penelitian ini adalah untuk mengetahui pengaruh dari Burnout Terhadap Kinerja Karyawan Pada BMT El-Munawar Medan. Masalah dalam penelitian ini adalah kinerja karyawan kurang optimal disebabkan kemampuan kerja karyawan kurang maksimal dan motivasi kerja karyawan menurun dalam melaksanakan pekerjaannya. Penelitian ini menggunakan metode Teknik analisis data menggunakan uji kualitas data, uji validitas, uji reliabilitas, uji asumsi klasik, uji normalitas, uji heterokedastisitas, uji autokorelasi, uji regresi sederhana, uji hipotesis, uji parsial t hitung (uji t), uji determinasi, dengan jumlah sampel sebanyak 15 responden yang ditentukan dengan teknik non probability sampling sebagai penentu jumlah responden yang ditujukan untuk BMT El-Munawar Medan, dimana metode pengumpulan data yang digunakan adalah angket.

Hasil penelitian menunjukkan bahwa burnout berpengaruh terhadap kinerja karyawan. Hal ini dibuktikan dengan ditolaknya hipotesis $\mathrm{H} 0$ melalui pengujian hipotesis dimana terdapat nilai t hitung $(34,264)>\mathrm{t}$ tabel $(2,160)$, dengan nilai sig $0,000<0,05$ menunjukkan $\mathrm{H} 0$ ditolak dan Ha diterima. Berdasarkan uji Determinasi Nilai R Square 0,989 atau 98,9\% menunjukkan sekitar $98,9 \%$ variabel kinerja karyawan (Y) dipengaruhi oleh burnout (X). Sementara sisanya sebesar $1,1 \%$ dipengaruhi oleh variabel yang tidak diteliti dalam penelitian ini. Maka penulis menarik kesimpulan dalam penelitian ini variabel burnout mempunyai pengaruh positif sebesar 0,989 atau 98,9\% terhadap kinerja karyawan pada BMT El-Munawar Medan.
\end{abstract}

\section{Artikel Info}

Received:

16 Februari 2018

Revised:

13 Maret 2018

Accepted:

20 Mei 2018

Keyword: Burnout, Kinerja, Motivasi

\section{A. Pendahuluan}

Bagi sebuah organisasi atau perusahaan, Sumber Daya Manusia (SDM) merupakan faktor yang sangat penting. Tidak mungkin satu organisasi akan terbentuk tanpa ada dukungan manusia baik sebagai anggota maupun pengurusnya. Bahkan tidak jarang 
keberlangsungan suatu organisasi amat tergantung dari manusia yang terlibat di dalamnya. Artinya maju atau mundurnya organisasi akan tampak dari keterampilan dan kinerja manusia yang berada dalam organisasi tersebut. Oleh karena itu, sumber daya manusia harus dikelola dan dikembangkan dengan baik agar organisasi atau perusahaan tersebut dapat bekerja dengan efektif dan efisien.

Dalam suasana bekerja pada setiap organisasi, setiap individu pasti memiliki masalah terlepas dari jabatan yang dipegangnya. Salah satu masalah yang sedang krusial di dunia kerja saat ini adalah burnout. Hal ini karena burnout seringkali menghambat laju kinerja para karyawan yang akhirnya merugikan perusahaan. Burnout seringkali muncul di dunia kerja dikarenakan rutinitas serta tekanan yang tinggi dalam kesehariaannya. ${ }^{1}$

Burnout adalah suatu gejala kelelahan fisik, emosional, sikap dan perilaku, perasaan ketidakpuasan terhadap diri serta ketidakpercayaan akan kemampuan diri dan kurangnya

${ }^{1}$ Yeni dan Idah Niswati, "Pengaruh Burnout Terhadap Motivasi Berprestasi Dalam Bekerja pada Sales", Vol. 5, No. 2, 2012, h. 34. hasrat pencapaian pribadi yang timbul akibat stres kerja berkepanjangan, reaksi keadaan yang menyertai seseorang ketika menghadapi stres tersebut dan merupakan respon dari interpersonal stressors dalam pekerjaan. Burnout akan berdampak negatif pada diri individu dan perusahaan, antara lain menyebabkan rendahnya atau menurunnya job performance karyawan. Semakin banyak stres kerja yang dialami karyawan maka karyawan akan semakin mungkin mengalami burnout dan kinerja karyawan akan semakin tidak maksimal. ${ }^{2}$ Para peneliti mengkaitkan burnout dengan beragam masalah kesehatan mental dan fisik, keburukan rumah tangga dan hubungan sosial meningkatnya pergantian dan ketidak hadiran. ${ }^{3}$ Kejenuhan kerja (Burnout) merupakan akibat stres kerja dan beban kerja yang paling umum. Gejala khusus

${ }^{2}$ Yeni dan Idah Niswati, "Pengaruh Burnout Terhadap Motivasi Berprestasi Dalam Bekerja pada Sales", Vol. 5, No. 2, 2012, h. 34.

Achamad Sani, "Analisis Pengaruh Burnout dan Kecerdasan Emosional (EI) Terhadap Kinerja Pegawai PT Bank Mega syari'ah Cabang Malang”, dalam Jurnal Ilmiah Program Studi Manajemen Fakultas Ekonomi Universitas Islam Negeri (UIN) Maliki Malang, h. 2. 
pada kejenuhan kerja ini antara lain kebosanan, depresi, pesimisme, kurang konsentrasi, kualitas kerja buruk, ketidakpuasan, absen, dan sakit. ${ }^{4}$

Salah satu faktor yang mempengaruhi tingkat keberhasilan suatu organisasi adalah kinerja karyawan. Kinerja karyawan adalah hasil kerja secara kualitas dan kuantitas yang dicapai oleh seorang karyawan dalam melaksanakan tugasnya sesuai dengan tanggung jawab yang diberikan kepadanya. Setiap perusahaan selalu mengharapkan karyawannya mempunyai prestasi, karena dengan memiliki karyawan yang berprestasi akan memberikan sumbangan yang optimal bagi perusahaan. Selain itu, dengan memiliki karyawan yang berprestasi perusahaan dapat meningkatkan kinerja perusahaannya. Apabila individu dalam perusahaan yaitu sumber daya manusia berjalan efektif, maka perusahaan juga tetap berjalan efektif. Dengan kata lain

\footnotetext{
${ }^{4}$ Puspa Ayu Maharani dan Akde Triyoga, "Kejenuhan Kerja (Bournot) dengan Kinerja Perawat dalam Pemberian asuhan Keperawatan", dalam Jurnal STIKES, Vol. 5, No. 2, 2012, h. 168.
}

kelangsungan suatu perusahaan ditentukan oleh kinerja karyawannya. ${ }^{5}$

Kinerja merupakan salah satu alat ukur kerja karyawan dalam sebuah perusahaan. Kinerja dari karyawan yang meningkat dapat dipastikan akan mempengaruhi pendapatan, yaitu pendapatan dari perusahaan juga pasti meningkat. ${ }^{6}$ Peningkatan kinerja karyawan bisa dilakukan dari berbagai sisi. Kinerja itu sendiri ialah keluaran yang dihasilkan oleh fungsi-fungsi atau indikator-indikator suatu pekerjaan atau suatu profesi dalam waktu tertentu. ${ }^{7}$

Usaha untuk meningkatkan kinerja karyawan, diantaranya adalah dengan memperhatikan kemampuan kerja karyawan. Karyawan adalah makhluk sosial yang menjadi kekayaan utama bagi setiap perusahaan. Mereka menjadi perencana, pelaksana dan pengendali yang selalu berperan aktif dalam mewujudkan tujuan perusahaan.

5Mangkunegara,
Sumber Daya Manemen
(Bandung: Remaja Rosdakarya, 2013), h. 67.

${ }^{6} \mathrm{~T}$. Hanny Handoko, Manajemen Personalia dan Sumberdaya Manusia, (Yogyakarta: BPFE, 2006), h. 43.

${ }^{7}$ Wirawan, Evaluasi Kinerja Sumber Daya Manusia Teori Aplikasi dan Penelitian, (Jakarta: Salemba Empat, 2009), h. 5 . 
Karyawan menjadi pelaku yang menunjang tercapainya tujuan, mempunyai pikiran, perasaan, dan keinginan yang dapat mempengaruhi sikap-sikapnya terhadap pekerjaannya. Sikap ini akan menentukan prestasi kerja dedikasi dan kecintaan terhadap pekerjaan yang dibebankan kepadanya. Sikap-sikap positif harus dibina, sedangkan sikap-sikap negatif hendaknya dihindarkan sedini mungkin. Sikap-sikap karyawan dikenal kepuasan kerja, stres, dan frustasi yang ditimbulkan oleh pekerjaan, peralatan, lingkungan, kebutuhan, dan sebagainya. ${ }^{8}$

Terdapat lima faktor yang dapat mempengaruhi kinerja, yaitu 1) faktor personal/individual meliputi pengetahuan, keterampilan (skill), kemampuan, kepercayaan diri, motivasi, dan komitmen yang dimiliki oleh setiap individu, 2) faktor kepemimpinan meliputi kualitas dalam memberikan dorongan, semangat, arahan, dan dukungan yang diberikan menejer dan team leader, 3) faktor tim meliputi:

\footnotetext{
${ }^{8}$ Mangkunegara, Manajemen Sumber Daya Manusia Perusahaan, (Bandung: Remaja Rosdakarya, 2013), h. 202.
}

kualitas dukungan dan semangat yang diberikan oleh rekan dalam satu tim, kepercayaan terhadap sesama anggota tim, kekompakan dan keeratan anggota tim, 4) faktor sistem meliputi: sistem kerja, fasilitas kerja atau infrastruktur yang diberikan oleh organisasi, proses organisasi, dan kultur kinerja dalam organisasi, 5) Faktor kontekstual (situasional) meliputi tekanan dan perubahan lingkungan eksternal dan internal. ${ }^{9}$

Menurut penelitian pendahuluan yang dilakukan peneliti, terdapat fenomena yang terjadi tentang kinerja karyawan yaitu: 1) Masih adanya karyawan yang merasa tertekan saat menghadapi pekerjaannya, dikarenakan pekerjaan yang dikerjakannya tidaksesuai dengan kemampuannya hingga mengakibatkan kelelahan dalam bekerja, sehingga membuat karyawan lebih sensitif ditambah lagi timbulnya masalah yang dialami karyawan baik di dalam perusahaan maupun di luar perusahaan. Selain itu adanya tuntunan

${ }^{9}$ Nyoman Adinda Adnyaswari dan I Gusti Ayu Dwi Adnyani, "Pengaruh Dukungan Sosial dan Burnout Terhadap Kinerja Perawat Rawat Inap RSUP SANGLAH", dalam E-Jurnal Manajemen Unud, Vol. 6, No. 5, 2017, h. 2483. 
pekerjaan yang berlebihan yang diberikan oleh atasan dengan waktu yang diberikan sangat terbatas, disamping itu karyawan cenderung lelah sehingga menunda dan menghindari pekerjaan karena merasa terbebani oleh pekerjaan yang diterimanya, ${ }^{10}$ 2) Timbulnya Burnout dalam diri karyawan menyebabkan tidak ada lagi motivasi untuk berprestasi yang muncul jika karyawan melakukan hanya pekerjaan kecil berulang-ulang kali seperti layaknya mesin. ${ }^{11}$

Berdasarkan hasil observasi pada BMT El-Munawar Medan menunjukkan kinerja karyawan kurang optimal disebabkan kemampuan kerja karyawan kurang maksimal dan motivasi kerja karyawan menurun dalam melaksanakan pekerjaannya.

Atas dasar itu, penting kiranya dilakukan suatu penelitian mengenai Pengaruh Burnout Terhadap Kinerja

\footnotetext{
${ }^{10}$ Dian Utari, "Pengaruh Stres Kerja dan Beban Kerja Terhadap Kinerja Karyawan Pada PT. Perkebunan Nusantara III (PERSERO) Medan", (Skripsi Sarjana Ekonomi Universitas Muhammadiyah Sumatera Utara, 2017), h. 4.

11 Yeni Indah Niswati, "Pengaruh Burnout Terhadap Motivasi Berprestasi dalam Bekerja Pada Sales", vol. 5, No. 2, 2012, h. 35.
}

Karyawan Pada BMT El-Munawar Medan. Dengan demikian, judul penelitian ini adalah "Pengaruh Burnout Terhadap Kinerja Karyawan Pada BMT El-Munawar Medan".

\section{B. Kajian Pustaka}

\section{Burnout}

\section{a. Pengertian Burnout}

Burnout sebagai kehilangan kekuatan fisik atau emosional dan motivasi yang biasanya sebagai akibat dari stres berkepanjangan atau frustasi, peran konflik, gaji atau upah yang rendah dan kurangnya sistem penghargaan terhadap kinerja yang mengakibatkan depresi. ${ }^{12}$

Burnout adalah sebagai kelelahan secara fisik, emosi dan mental yang terjadi karena individu berada dalam situasi yang menuntut keterlibatan emosi secara berlebihan dan berkepanjangan. ${ }^{13}$ Burnout

\footnotetext{
${ }^{12}$ Nikki Rasuna Katarin, “Burnout Pada Karyawan Ditinjau Dari Persepsi Budaya Organisasi dan Motivasi Intrinsik di PT. Krakatau Steel”, (Skripsi Sarjana Psikologi Universitas Sebelas Maret Surakarta, 2011), h. 13.

${ }^{13}$ Yeni dan Idah Niswati, "Pengaruh Burnout Terhadap Motivasi Berprestasi
} 
merupakan respon individu terhadap stres yang dialaminya dalam situasi kerja yang ditandai dengan adanya kelelahan fisik dan psikis, perasaan tidak berdaya, serta berkembangnya konsep diri yang negatif terhadap pekerjaan dan kehidupannya. Burnout sebagai suatu proses dimana sikap dan tingkah laku individu berubah menjadi negatif dalam merespon pekerjaannya. Proses perubahan tingkah laku ini dimulai pada saat adanya ketidak seimbangan antara kemampuan yang dimiliki individu dengan tuntutan yang harus dihadapinya. Hal ini menyebabkan kelelahan yang sangat tinggi dalam diri individu. Selanjutnya terjadi perubahan tingkah laku individu ke arah yang negatif.

\section{b. Ayat Al-Qur'an Tentang Burnout}

\section{1) (QS. Yunus [10]: 62)}

Artinya: Ingatlah, Sesungguhnya wali-wali Allah itu, tidak ada kekhawatiran terhadap mereka dan tidak (pula) mereka bersedih hati. ${ }^{14}$

\section{2) (QS. An-Nisaa [4]: 79)}

Artinya: Apa saja nikmat yang kamu peroleh adalah dari Allah, dan apa

dalam Bekerja pada Sales" Vol. 5, No. 2, 2012, h. 35.

${ }^{14}$ Q.S. Yunus: 62 saja bencana yang menimpamu, Maka dari (kesalahan) dirimu sendiri. Kami mengutusmu menjadi Rasul kepada segenap manusia.dan cukuplah Allah menjadi saksi.

\section{c. Karakteristik Burnout}

Ada 11 karakteristik pada penderita burnout, yaitu: ${ }^{15}$

1) Kelelahan yang merupakan proses kehilangan energi disertai keletihan; penderita burnout mengalami kelelahan fisik yang ditandai dengan perasaan kekurangan energi dan merasa lelah sepanjang waktu.

2) Lari dari kenyataan: penderita burnout cenderung menghindar dari tanggung jawab pekerjaannya serta sering membolos kerja.

3) Kebosanan dan sinisme: disebebkan oleh tugas yang kurang menantang, kurang makna dan tidak beragam akan menimbulkan perasaan jemu yang melahirkan kehilangan ketertarikan terhadap pekerjaan

15 Rita Andarika, "Burnout pada Perawat Puteri RS St. Elizabeth Semarang Ditinjau dari Dukungan Sosial", dalam Jurnal PSYCHE, Vol. 1, No. 1, 2004, h. 3. 
maupun orang-orang di lingkungan pekerjaan.

4) Tidak sabar dan mudah tersinggung; penderita burnout cenderung lebih mudah marah dan tersinggung disebabkan halhal tidak penting, karena keadaan yang dirasakannya.

5) Merasa hanya dirinya yang dapat menyelesaikan semua permasalahan; hal ini didasari karena berkembangnya perasaan menjadi manusia super, yakni merasa sanggup menangani sesuatu, tidak memerlukan bantuan sehingga menjadi tinggi hati karenanya.

6) Merasa tidak dihargai: hal ini terjadi apabila puncak ambisi individu terlalu tinggi, mendorong dirinya terlalu keras sehingga ketidaksesuaian dengan realitas menyulut kekecewaan dan perasaan tidak dihargai.

7) Mengalami disorientasi: kehilangan arah serta tujuan hidupnya, tidak tahu apa target pekerjaannya.

8) Keluhan psikosomatis: penderita burnout sering mengalami sakit kepala, mual, sakit punggung dan keluhan fisik lainnya yang tidak diketahui apa penyebabnya.

9) Curiga tanpa alasan: penderita burnout menjadi mudah curiga terhadap orang lain karena berkembangnya pendapat negatif dalam diri mereka yang membuat mereka menjaga jarak dengan orang lain serta menjauh dari lingkungan sosial.

10) Depresi adalah gangguan mood, kondisi emosional berkepanjangan, yang mewarnai seluruh proses berfikir, berperasaan serta berprilaku seseorang.

11) Penyangkalan; merupakan perilaku menolak menghadapi kenyataan yang tidak menyenangkan.

\section{d. Indikator Burnout}

Burnout memiiki empat indikator yang terdiri atas kelelahan fisik atau kekurangan energi, kelelahan emosional, kurangnya aktualisasi diri dan depersonalisasi. ${ }^{16}$

${ }^{16}$ Muchlisin Riadi, Burnout (Kelelahan Kerja); Indikator, Faktor \& Gejalanya, didapat dari 
1) Kelelahan Emosional

Merupakan suatu indikator dari kondisi burnout yang berwujud perasaan sebagai hasil dari emosional yang berlebihan yang ditandai hilangnya perasaan dan perhatian, kepercayaan, minat dan semangat. Orang yang mengalami kelelahan emosional ini akan merasa hidupnya kosong, lelah dan tidak dapat lagi mengatasi tuntutan pekerjaannya.

2) Kurangnya Aktualisasi Diri

Merupakan indikator dari kurangnya aktualisasi diri, rendahnya motivasi kerja dan penurunan rasa percaya diri. Seringkali kondisi ini terlihat pada kecenderungan dengan rendahnya prestasi yang dicapainya.

\section{3) Depersonalisasi}

Depersonalisasi adalah tendensi kemanusiaan terhadap sesama yang merupakan pengembangan dari sikap sinis terhadap karier, dan kinerjanya sendiri. Seseorang yang mengalami masalah depersonalisasi merasa tidak ada satupun aktivitas yang

http://www.kajianpustaka.com/2016/02/bur nout-kelelahan-kerja-indikator.html [home page on-line]: Internet (diakses tanggal 27 November 2017). dilakukannya bernilai atau berarti. Sikap ini ditunjukkan melalui perilaku masa bodoh, bersikap sinis, tidak berperasaan dan tidak memperhatikan kepentingan orang lain.

2. Kinerja Karyawan

\section{a. Pengertian Kinerja}

Dalam melaksanakan aktifitas kerjanya, karyawan menghasilkan sesuatu yang disebut kinerja. Kinerja adalah hasil kerja yang dapat dicapai oleh seseorang atau sekelompok orang dalam suatu organisasi sesuai dengan wewenang dan tanggung jawab masingmasing dalam upaya mencapai tujuan organisasi yang dilakukan secara legal, tidak melanggar hukum dan sesuai dengan norma dan etika. Kinerja merupakan hasil kerja seseorang karyawan selama periode waktu tertentu dibandingkan dengan berbagai kemungkinan misalnya standar yang ditetapkan, target, dan sasaran, atau kriteria yang telah ditentukan terlebih dahulu dan disepakati bersama. Berkaitan dengan hal di atas tersebut terdapat beberapa definisi kinerja menurut para ahli, diantaranya:

Kinerja merupakan hasil kerja dan perilaku kerja yang telah dicapai dalam menyelesaikan tugas-tugas dan 
tanggung jawab yang diberikan dalam suatu periode tertentu. ${ }^{17}$

Kinerja merupakan suatu kondisi yang harus diketahui dan dikonfirmasikan kepada pihak tertentu untuk mengetahui tingkat pencapaian hasil individu dihubungkan dengan visi yang diemban suatu organisasi, serta mengetahui dampak positif dan negatif dari suatu kebijakan operasional. ${ }^{18}$

Kinerja atau performance merupakan gambaran mengenai tingkat pencapaian pelaksanaan suatu program kegiatan atau kebijakan dalam mewujudkan sasaran, tujuan, visi dan misi organisasi yang dituangkan melalui perencanaan strategis suatu organisasi. ${ }^{19}$

Dari definisi-definisi tersebut, dapat diambil kesimpulan bahwa kinerja pada hakikatnya mempunyai pengertian yang sama. Kinerja merupakan hasil yang dicapai oleh karyawan dalam periode waktu tertentu

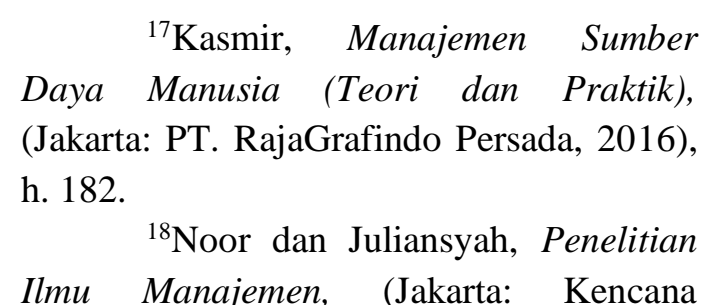
Predana Media Group, 2013), h. 270.

${ }^{19}$ Moeheriono, Pengukuran Kinerja Berbasis Kompetensi, (Bandung: PT. Remaja Rosdakarya, 2013), h. 195. dalam suatu organisasi yang dilakukan sesuai dengan wewenang dan tanggung jawab masing-masing dalam upaya untuk mencapai tujuan suatu organisasi.

\section{b. Ayat Al-Qur'an Tentang Kinerja 1) (QS. At-Taubah [9]: 105)}

Artinya: Bekerjalah kamu, Maka Allah dan Rasul-Nya serta orang-orang mukmin akan melihat pekerjaanmu itu, dan kamu akan dikembalikan kepada (Allah) yang mengetahui akan yang ghaib dan yang nyata, lalu diberitakanNya kepada kamu apa yang telah kamu kerjakan. ${ }^{20}$

\section{2) (QS. Al-Ahqaaf [46]: 19)}

Artinya: Dan bagi masing-masing mereka derajat menurut apa yang telah mereka kerjakan dan agar Allah mencukupkan bagi mereka (balasan) pekerjaan-pekerjaan mereka sedang mereka tiada dirugikan. ${ }^{21}$

\section{c. Karakteristik Kinerja Karyawan}

Karakteristik orang yang mempunyai kinerja tinggi adalah sebagai berikut: ${ }^{22}$

${ }^{20}$ Q.S. At-Taubah: 105

${ }^{21}$ Q.S. Al-Ahqaaf: 19

${ }^{22}$ Mangkunegara, Manajemen Sumber Daya Manusia, (Bandung: Remaja Rosdakarya, 2002), h. 68. 
1) Memiliki tanggung jawab pribadi yang tinggi.

2) Berani mengambil dan menanggung resiko yang dihadapi.

3) Memiliki tujuan yang realistis.

4) Memiliki rencana kerja yang menyeluruh dan berjuang untuk merealisasi tujuannya.

5) Memanfaatkan umpan balik (feed back) yang konkrit dalam seluruh kegiatan kerja yang dilakukannya.

6) Mencari kesempatan untuk merealisasikan rencana yang telah diprogramkan.

\section{d. Indikator Kinerja}

Dengan mengetahui kelemahan dan kelebihan, hambatan dan dorongan, atau berbagai faktor sukses bagi kinerja karyawan serta institusi maka terbukalah jalan menuju profesionalisme, yaitu memperbaiki kesalahan-kesalahan yang dilakukan selama ini.

Adapun indikator kinerja
adalah: $^{23}$

1) Kualitas kerja

${ }^{23}$ Mangkunegara, Manajemen Sumber Daya Manusia, (Bandung: PT. Remaja Rosdakarya, 2009), h. 75.
Kualitas kerja adalah kemampuan menghasilkan sesuai dengan kualitas standar yang ditetapkan perusahaan.

2) Kuantitas kinerja

Kuantitas kinerja adalah kemampuan menghasilkan sesuai dengan jumlah standar yang ditetapkan perusahaan.

3) Keandalan kerja

Keandalan kerja adalah kemampuan karyawan memberikan integritas pribadi dalam meningkatkan tata kelola perusahaan dengan prinsipprinsip terbaik.

4) Sikap Kerja

Sikap terhadap perusahaan karyawan lain serta kerjasama diantara rekan kerja, ketaatan pada atasan/ pimpinan juga dalam hal ini bisa memotivasi para karyawan untuk meningkatkan kinerjanya.

Menurut pendapat lain indikator kinerja yaitu: ${ }^{24}$

1) Tujuan suatu keadaan yang lebih baik yang ingin dicapai masa yang akan datang.

2) Standar, suatu ukuran apakah tujuan yang diinginkan dapat dicapai.

24 Wibowo, Manajemen Kinerja, (Jakarta: Rajawali Pers, 2014), h. 86. 
3) Umpan balik, masukan yang dipergunakan untuk mengukur kemajuan kinerja, standar kinerja.

4) Alat atau sarana, faktor penunjang untuk pencapaian tujuan.

5) Kompetensi, kemampuan yang dimiliki seseorang untuk menjelaskan pekerjaan yang diberikan kepadanya.

6) Motivasi, alasan atau pendorong bagi seseorang untuk melakukan sesuatu.

7) Peluang, pekerja perlu mendapat kesempatan untuk menunjukkan prestasi kerjanya.

\section{Metode Penelitian}

\section{Pendekatan Penelitian}

Pendekatan yang digunakan dalam penelitian ini adalah pendekatan asosiatif. Pendekatan asosiatif bertujuan untuk menganalisis permasalahan hubungan suatu variabel dengan variabel lainnya. Sementara itu, dalam pendekatan asosiatif ini dimana kecenderungan data yang digunakan dalam metode kuantitatif. ${ }^{25}$

\section{Teknik Analisis Data}

${ }^{25}$ Azuar Juliandi dan Irfan, Metode Penelitian, (Bandung: Cipta Pustaka Media Perintis, 2013), h. 90.
Analisa data dilakukan dengan cara yaitu analisis Kuantitatif. Analisis yang dilakukan terhadap data antara lain: Uji Kualitas Data yang dilakukan dengan cara validitas dan releabilitas, uji normalitas data, uji regresi sederhana, pengujian hipotesis dilakukan dengan uji determinan.

\section{Hasil Penelitian}

\section{Uji Asumsi Klasik}

Bagian ini adalah menganalisis data yang berasal dari data -data yang telah dideskrifsikan dari data sebelumnya atau subbab yang merupakan deskripsi data. Data yang dianalisis dimulai dari asumsi-asumsi yang digunakan untuk suatu statistik tertentu dengan melakukan pengujian hipotesis untuk pengambilan kesimpulan.

Dengan kriteria:

\section{a Uji Normalitas}

Pengujian normalitas data dilakukan untuk melihat apakah dalam model regresi, variabel dependent dan independennya memiliki distribusi normal atau tidak. Jika data menyebar disekitar garis diagonal dan mengikuti arah garis diagonal maka model regresi memenuhi asumsi normalitas. 
Normal P-P Plot of Regression Standardized Residual

Dependent Variable: KINERJA

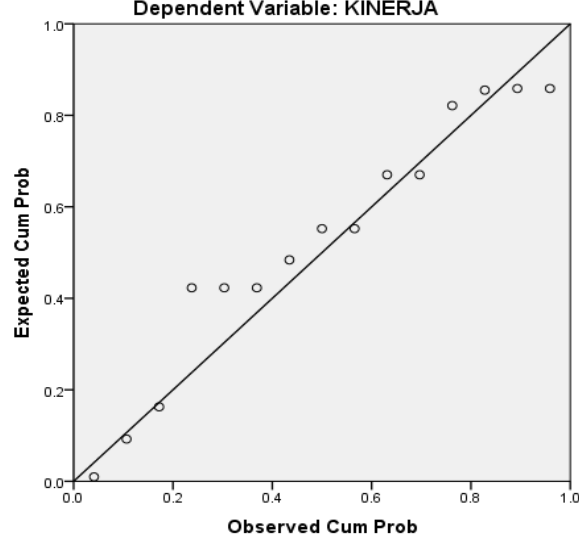

Gambar di atas menunjukkan bahwa titik-titik telah membentuk dan mengikuti arah garis diagonal pada gambar, dengan demikian dapat dinyatakan bahwa data telah terdistribusi secara normal.

\section{b. Uji Heterokedastisitas}

Heterokedastisitas digunakan untuk menguji apakah dalam model korelasi, terjadi ketidaksamaan varians dari residual dari suatu pengamatan yang lain. Jika variasi residual dari suatu pengamatan lain tetap, maka disebut homokedastisitas, dan jika varians berbeda disebut heterokedastisitas. Model yang baik adalah tidak terjadi heterokedastistas.

Dasar pengambilan keputusannya adalah: jika pola tertentu, seperti titiktitik (poin-poin) yang ada membentuk suatu pola tertentu yang teratur, maka terjadi heterodastisitas. Jika tidak ada pola yang jelas, serta titik-titik (poinpoin) menyebar dibawah 0 pada sumbu y maka tidak terjadi heterokedastisitas.

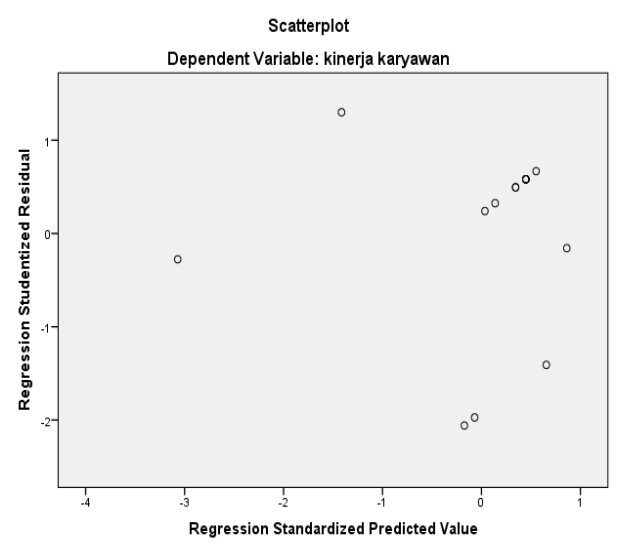

Gambar di atas memperlihatkan titik-titik menyebar secara acak, tidak membentuk pola yang jelas/ teratur, serta tersebar baik diatas maupun dibawah angka 0 pada $\mathrm{Y}$.

\section{c. Uji Autokorelasi}

Uji ini digunakan untuk menguji apakah dalam sebuah model regresi linear ada korelasi antara kesalahan pengganggu pada period eke $t$ dengan kesalahan pada periode $\mathrm{t}-1$ (sebelumnya). Jika terjadi korelasi, maka dinamakan pada problem autokorelasi. Model regresi yang baik adalah bebas dari autokorelasi. Hasil uji autokorelsi menggunakan SPSS menunjukkan nilai Durbin Watson adalah 1,592. Dengan demikian tidak ada autokorelasi di dalam model regresi. 
Salah

satu

cara

mengidentifikasinya adalah dengan melihat nilai Durbin Watson (D-W).

a) Jika nilai $\mathrm{D}-\mathrm{W}$ di bawah -2 berarti ada autokorelasi positif

b) Jika nilai $\mathrm{D}-\mathrm{W}$ di bawah -2 sampai +2 berarti tidak ada autokorelasi

c) Jika nilai $\mathrm{D}-\mathrm{W}$ di atas +2 berarti ada autokorelasi negative

\section{Regresi Linear Sederhana}

Analisis regresi disusun untuk melihat hubungan yang terbangun antara variabel penelitian, apakah hubungan yang terbangun positif atau hubungan negative.

Berdasarkan olahan data yang telah dilakukan, maka dapat diketahui bahwa model hubungan dari analisis regeresi linier sederhana memperlihatkan bahwa semua variabel $\mathrm{X}$ (Burnout) memiliki koefisien yang positif, berarti seluruh variabel bebas mempunyai pengaruh yang searah terhadap variabel Y (kinerja karyawan).

\section{Pengujian Hipotesis}

Pengujian hipotesis pada penelitian seperti yang dijabarkan berikut ini:

\section{a Uji Parsial (Uji t)}

Uji statistik t dilakukan untuk menguji apakah variabel bebas (X) secara individual mempunyai hubungan yang signifikan atau tidak terhadap variabel terikat $(\mathrm{Y})$.

Untuk mengetahui tingkat pengaruh variabel burnout terhadap kinerja karyawan dapat dilihat pada tabel di bawah ini:

Tabel

Pengaruh Burnout Terhadap Kinerja Karyawan

Coefficients $^{a}$

\begin{tabular}{|l|r|r|r|c|c|}
\hline Model & \multicolumn{2}{|c|}{$\begin{array}{c}\text { Unstandardiz } \\
\text { ed } \\
\text { Coefficients }\end{array}$} & $\begin{array}{c}\text { Stan } \\
\text { dardi } \\
\text { zed } \\
\text { Coef } \\
\text { ficien } \\
\text { ts }\end{array}$ & $\mathrm{t}$ & Sig. \\
\cline { 2 - 4 } & $\mathrm{B}$ & $\begin{array}{r}\text { Std. } \\
\text { Error }\end{array}$ & Beta & & \\
\hline $\begin{array}{l}\text { (Cons } \\
\text { tant) } \\
\text { BURN } \\
\text { OUT }\end{array}$ & 3.083 & $\begin{array}{r}1.14 \\
8\end{array}$ & & 2.685 & .019 \\
.027 & .995 & 34.264 & .000 \\
\hline
\end{tabular}

a. Dependent Variable: kinerja karyawan Sumber: Hasil Pengolahan Data SPSS.21

Pada tabel di atas terdapat pengaruh burnout terhadap kinerja dengan diperoleh nilai $\mathrm{t}$ hitung 34,264 > t tabel 2,160 dengan probabilitas sig. 0,000 $\leq 0,05$. Hal tersebut menunjukkan hipotesis nol (H0) di tolak dan dapat disimpulkan bahwa burnout (X) secara parsial mempunyai pengaruh yang signifikan terhadap kinerja (Y) pada BMT El-Munawar Medan. 
Dengan taraf signifikan $5 \%$ uji dua pihak dan derajat kebebasan $(\mathrm{dk})=$ n-2 Keterangan:

a) Bila $t_{\text {hitung }}>t_{\text {tabel}}$, maka ada hubungan signifikan antara variabel $\mathrm{x}$ dan $\mathrm{y}$.

b) Bila $t_{\text {hitung }}<t_{\text {tabel }}$, maka tidak ada hubungan signifikan antara variabel $\mathrm{x}$ dan $\mathrm{y}$.

Hal ini menunjukkan bahwa burnout berpengaruh terhadap kinerja karyawan pada BMT El-Munawar Medan.

\section{b Uji Determinasi}

Untuk mengetahui tingkat reliabilitas pada variabel burnout dan kinerja karyawan dapat dilihat pada perhitungan di bawah ini:

$$
\begin{aligned}
\mathrm{D} & =(\mathrm{R})^{2} \text { X } 100 \% \\
& =(0,995)^{2} \times 100 \% \\
& =98,9 \%
\end{aligned}
$$

Dari hasil uji determinasi diatas dapat diambil kesimpulan bahwa burnout berpengaruh terhadap kinerja karyawan sebesar 98,9\%, sedangkan $1,1 \%$ dipengaruhi oleh variabel lain.

\section{E. Kesimpulan}

Hasil penelitian dan pembahasan yang dilakukan oleh penulis mengenai pengaruh burnout terhadap kinerja karyawan pada BMT El-Munawar Medan, maka dapat disimpulkan sebagai berikut: Burnout perpengaruh terhadap kinerja karyawan yang dinyatakan dengan hasil perhitungan $\mathrm{t}$ hitung> t tabel yaitu 34,264>2,160 sehingga disimpulkan $\mathrm{t}$ hitung berada dipenolakan $\mathrm{H} 0$ dan Ha diterima.

Berdasarkan uji Determinasi Nilai R Square sebesar 0,989 atau $98,9 \%$ variabel kinerja karyawan (Y) dipengaruhi oleh burnouut (X). Sementara sisanya sebesar $1,1 \%$ dipengaruhi oleh variabel yang tidak diteliti dalam penelitian ini.

\section{Daftar Pustaka}

Achamad Sani. "Analisis Pengaruh Burnout dan Kecerdasan Emosional (EI) Terhadap Kinerja Pegawai PT Bank Mega syari'ah Cabang Malang”. Jurnal Ilmiah Program Studi Manajemen Fakultas Ekonomi Universitas Islam Negeri (UIN) Maliki Malang.

Andie Kamarus Zaman. "Hubungan Antara Burnout Dengan Kualitas Pelayanan Perawat Rumah Sakit Umum Daerah Kabupaten Tangerang". Skripsi Sarjana Psikologi Universitas Islam Negeri Syarif Hidayatullah, 2007. 
Azuar Juliandi dan Irfan. Metode Penelitian. Bandung: Cipta Pustaka Media Perintis, 2013.

Azuar juliandi, dkk. Metode Penelitian Bisnis. Medan: UMSU PRESS, 2015.

Bambang Prasetyo dan Lina Miftahul Jannah. Metode Penelitian Kuantitatif. Jakarta: PT. Grafindo Persada, 2006.

Dian Utari. "Pengaruh Stres Kerja dan Beban Kerja Terhadap Kinerja Karyawan Pada PT. Perkebunan Nusantara III (PERSERO) Medan". Skripsi Sarjana Ekonomi Universitas Muhammadiyah Sumatera Utara, 2017.

Dissy Viana Andani Putri. "Analisis Pengaruh Dukungan Sosial Terhadap Burnout Pada Perawat". Skripsi Sarjana Ekonomika dan Bisnis Universitas Diponegoro, 2014.

Imam Ghozali. Aplikasi Analisis Multivariate dengan programSPSS. Edisi kedua. Semarang: Badan Penerbit Universitas Diponegoro, 2001

Inra Risma Trisnawaty Bubar-Butar. "Hubungan Antara Burnout Dengan Prestasi Kerja Insurance Agents Prudential Cabang Kantor Graha Prestasi Medan". Skripsi
Sarjana Psikologi Universitas HKBP Nommensen, 2015.

Kasmir. Manajemen Sumber Daya Manusia (Teori dan Praktik). Jakarta: PT. RajaGrafindo Persada, 2016.

Mangkunegara. Manajemen Sumber Daya Manusia. Bandung: Remaja Rosdakarya, 2002.

Mangkunegara. Manajemen Sumber Daya Manusia. Bandung: PT. Remaja Rosdakarya, 2009.

Mangkunegara. Manajemen Sumber Daya Manusia Perusahaan. Bandung: Remaja Rosdakarya, 2013.

Moeheriono. Pengukuran Kinerja Berbasis Kompetensi. Bandung: PT. Remaja Rosdakarya, 2013.

Muchlisin Riadi, Burnout (Kelelahan Kerja); Indikator, Faktor \& Gejalanya, didapat dari http://www.kajianpustaka.com/20 16/02/burnout-kelelahan-kerjaindikator.html [home page online]: Internet diakses tanggal 27 November 2017.

Nikki Rasuna Katarin. "Burnout Pada Karyawan Ditinjau Dari Persepsi Budaya Organisasi dan Motivasi Intrinsik di PT. Krakatau Steel”. Skripsi Sarjana Psikologi Universitas Sebelas Maret Surakarta, 2011. 
Noor dan Juliansyah. Penelitian Ilmu

Manajemen. Jakarta: Kencana

Predana Media Group, 2013.

Nyoman Adinda Adnyaswari.

"Pengaruh Dukungan Sosial dan

Burnout Terhadap Kinerja

Perawat Rawat Inap RSUP

SANGLAH". dalam E-Jurnal

Manajemen Unud, Vol. 6, No. 5, 2017.

Puspa Ayu Maharani dan Akde Triyoga. "Kejenuhan Kerja (Bournot) dengan Kinerja Perawat dalam Pemberian asuhan Keperawatan". dalam Jurnal STIKES, Vol. 5, No. 2. 2012.

Rita Andarika. "Burnout pada Perawat Puteri RS St. Elizabeth Semarang Ditinjau dari Dukungan Sosial". dalam Jurnal PSYCHE. Vol. 1, No. 1, 2004.

Saifuddin azwar. Metode Penelitian. Yogyakarta: Pustaka Pelajar, 2003.

Sugiyono. Metode Penelitian Administrasi. Bandung: CV. Alfabeta, 2006.
Sugiyono. Metode Penelitian Bisnis. Bandung: Alfabeta, 2012.

T. Hanny Handoko. Manajemen Personalia dan Sumberdaya Manusia. Yogyakarta: BPFE, 2006.

Wirawan. Evaluasi Kinerja Sumber Daya Manusia Teori Aplikasi dan Penelitian. Jakarta: Salemba Empat, 2009.

Wibowo, Manajemen Kinerja, Jakarta: Rajawali Pers, 2014.

Yeni dan Idah Niswati. "Pengaruh Burnout Terhadap Motivasi Berprestasi Dalam Bekerja pada Sales" Vol. 5, No. 2, 2012. 